\title{
The role of catch crops in the ecological intensification of spring cereals in organic farming under Nordic climate
}

\author{
Jordi Doltra*, Jørgen E. Olesen \\ Aarhus University, Department of Agroecology, Blichers Allé 20, P.O. Box 50, DK-8830 Tjele, Denmark
}

\section{A R T I C L E I N F O}

\section{Article history:}

Received 15 March 2011

Received in revised form 17 February 2012

Accepted 13 March 2012

\section{Keywords:}

Spring oat

Spring barley

Legumes

Nitrogen

Cropping systems

\begin{abstract}
A B S T R A C T
Catch crops can contribute to nitrogen supply of following crops through uptake of excess soil mineral nitrogen $(\mathrm{N})$ and through biological $\mathrm{N}$ fixation. The contribution of catch crops to the ecological intensification of organic arable systems was investigated using data of a 12-year field experiment carried out at three sites in Denmark. This study focused on the yields of spring oats and spring barley in systems with and without manure in two different cropping systems ( 02 and 04 ) that differed in the proportion of legume-based catch crops (O2 lower and $\mathrm{O} 4$ higher) and in the rotation composition (grass-clover green manure in $\mathrm{O} 2$ and pulse crops in 04 ). Three consecutive four-year crop cycles were established at three locations representative of different soil types (loamy sand, sandy loam and coarse sand) and climatic conditions. Crop management and soil operations were performed following common practices in organic farming. Measurements of dry matter (DM) and $\mathrm{N}$ content of grain cereals at harvest, aboveground biomass in catch crops and green manure crops in autumn and of the green manure crop at the first cutting were performed. The effect of catch crops on grain yield varied with cereal and catch crop species, soil and rotation type, and the application of $\mathrm{N}$ in manure. Higher yield increases from previous catch crops were obtained for spring oat than for spring barley with mean estimates of the apparent $\mathrm{N}$ recovery efficiency of $\mathrm{N}$ in above-ground catch crops of $69 \%$ and $46 \%$, respectively. However, lower autumn $\mathrm{N}$ in catch crops undersown in high yielding cash crop was also observed. For spring oats mean grain yield benefits of including catch crops varied from 0.2 to $2.4 \mathrm{Mg} \mathrm{DM} \mathrm{ha}^{-1}$ depending on location, manure use and cycle of the rotation. In spring barley mean grain yield benefits from catch crops varied from 0.1 to $1.5 \mathrm{Mg} \mathrm{DM} \mathrm{ha}^{-1}$. There was a tendency for the effect of catch crop on grain yield to increase over time. These results indicate that in Nordic climates catch crops can contribute to the ecological intensification of spring cereals, not only by reducing the nitrate leaching and increasing $\mathrm{N}$ retention, but also by improving yields. Management practices in relation to catch crops must be adapted to the specific soil and cropping systems.
\end{abstract}

(c) 2012 Elsevier B.V. All rights reserved.

\section{Introduction}

The projected increase of human population by more than two billion by the middle of the century (UN, 2005) points to the need for intensifying agriculture at a global scale to match the projected increase in demands for food, feed, fiber and biofuels. However, agriculture is not only responsible for producing the required crop and livestock products to sustain the population. It also plays a determining role in delivering other ecosystem services such as those that protect the quality of the environment (MEA, 2005), and, intrinsically, agriculture is also part of the culture of nations, regions and people. It is with these considerations that raising grain

\footnotetext{
* Corresponding author. Current address: Centro de Investigación y Formación Agrarias, Gobierno de Cantabria, c/Héroes 2 de Mayo, 27, 39600 Muriedas, Cantabria, Spain. Tel.: +34 942254045; fax: +34 942269011.

E-mail address: jordidoltra@cifacantabria.org (J. Doltra).
}

yields without negatively affecting the environment and the longterm sustainability of the production has been identified as crucial for agricultural development (Foresight, 2011), and this has been defined as ecological intensification of agriculture (Cassman, 1999). Hochman et al. (2011) define several attributes desirable in an ecologically intensified agriculture focused on increasing production, improving resource use efficiency, minimizing environmental impacts and achieving social outcomes. Organic farming addresses many of these attributes and makes major use of the biological regulation mechanisms to replace external inputs while preserving biodiversity, one of the fundamental principles in ecological intensification (Doré et al., 2011). In some European countries such as Denmark or Switzerland it has been pointed out that the increase in potential crop yield due to the development of new technologies and crop breeding has been higher than that of actual crop yields (Finger, 2011). This is due to the implementation of agroenvironmental measures and policies affecting crop production and management (Finger, 2010). It is therefore a major challenge in 
Denmark to raise food production under the ecological intensification fundamentals to reduce "increasing yield gaps", and that could be achieved through developing more efficient and productive systems in organic farming.

Cereals are by far the most extensively cultivated crops globally, and they are used for food, feed and biofuels. In organic farming systems under temperate climatic conditions, cereals have lower yields compared with similar conventional systems (Doltra et al., 2011). In organic cereal production, the management practices adopted to control weeds, pests and diseases and the optimization of nutrient availability to the crops determine to a large extent the yields obtained (Rasmussen et al., 2006; Olesen et al., 2009). As the best management practices for organic systems are still being tested for specific crop species and sites, there is a high potential to improve organic cereal grain yields. This is in contrast with the intensive systems using high amounts of fertilizers and pesticides, where evidences of yield stagnation are now being reported (Dobermann and Cassman, 2005; Finger, 2010; Brisson et al., 2010).

Catch crops can be used as biological tools to improve the nitrogen $(\mathrm{N})$ economy of crop rotations (Thorup-Kristensen et al., 2003). In Nordic climates $\mathrm{N}$ leaching losses of nitrate or ammonium outside the main growing season can be effectively reduced by growing catch crops (e.g., Askegaard et al., 2005; Känkänen and Eriksson, 2007; Hauggaard-Nielsen et al., 2009a; Engström et al., 2010; Doltra et al., 2011). The $\mathrm{N}$ retained in catch crops can be made available for the succeeding spring cereal by timing the soil incorporation of the catch crop relative to cereal sowing to allow decomposition of the catch crop residues. Legume catch crops can improve $\mathrm{N}$ supply through biological $\mathrm{N}$ fixation (BNF), in particular in organic farming systems (Lampkin, 1998; Thorup-Kristensen et al., 2003; Askegaard and Eriksen, 2008; Hauggaard-Nielsen et al., 2009a). However, an undersown catch crop may compete for light and soil resources (water and nutrients) with the main cash crop (typically cereals), which would reduce yields of the cash crop. Känkänen and Eriksson (2007) compared seventeen different catch crop species for undersowing with spring barley, concluding that Italian ryegrass, although very effective in diminishing $\mathrm{N}$ leaching, competed severely with the spring cereal, while white clover and red clover did not greatly affect grain yield. In a meta-analysis Tonitto et al. (2006) found that in comparison with fertilized crops without overwintering catch crops, unfertilized legume cover crop based systems reduced on average crop yields and nitrate leaching by 10 and $40 \%$, respectively.

Few long-term studies have investigated the role of catch crops on the yields of cash crops and the $\mathrm{N}$ balance of crop rotations (Olesen et al., 2007, 2009). These studies are important to follow the fate of $\mathrm{N}$ in a given system, to quantify the efficiency of $\mathrm{N}$ supplied from catch crops, the effect of catch crop $\mathrm{N}$ on cash crop yield, and the consequences for $\mathrm{N}$ losses considering possible differences in the timing of the $\mathrm{N}$ turnover and loss processes from growing catch crops (Thorup-Kristensen, 1994; Hauggaard-Nielsen et al., 2009b). In this study we used results from a long-term field experiment to investigate the effects of growing catch crops on the grain yield of spring cereals in organic systems with and without application of manure growing in three different soils. The objective was to quantify the yield benefits from including legume-based catch crops in realistic organic arable cropping systems on characteristic soil types in Denmark.

\section{Materials and methods}

\subsection{General details}

The experiment was carried out in an organic crop rotation at three sites in Denmark with different soil types and climate.
Jyndevad is located in Southern Jutland $\left(54^{\circ} 54^{\prime} \mathrm{N}, 9^{\circ} 08^{\prime} \mathrm{E}\right)$ on coarse sand (Orthic Haplohumod), Foulum is located in Central Jutland $\left(56^{\circ} 30^{\prime} \mathrm{N}, 9^{\circ} 35^{\prime} \mathrm{E}\right)$ on loamy sand (Typic Hapludult) and Flakkebjerg is located in Western Zealand $\left(55^{\circ} 20^{\prime} \mathrm{N}, 11^{\circ} 23^{\prime} \mathrm{E}\right)$ on sandy loam (Typic Agrudalf). The soils can be considered as free draining and have in the top $25 \mathrm{~cm}$ layer $4.5 \%$ clay $(<2 \mu \mathrm{m}), 12.4 \%$ silt $(2-20 \mu \mathrm{m})$, $18 \%$ fine sand ( $20-200 \mu \mathrm{m}), 73.1 \%$ coarse sand (200-2000 $\mu \mathrm{m}), 2.0 \%$ organic matter and pH 6.1 at Jyndevad; $8.8 \%$ clay, $13.3 \%$ silt, $47 \%$ fine sand, $27.2 \%$ coarse sand, $3.8 \%$ organic matter and pH 6.5 at Foulum; and $15.5 \%$ clay, $12.4 \%$ silt, $47.4 \%$ fine sand, $22.9 \%$ coarse sand, $1.7 \%$ organic matter and pH 7.4 at Flakkebjerg. A more detailed description of soils can be found in Olesen et al. (2000) and Berntsen et al. (2004). Average annual temperature and rainfall during the period 1961-1990 were $7.9^{\circ} \mathrm{C}$ and $964 \mathrm{~mm}, 7.3^{\circ} \mathrm{C}$ and $704 \mathrm{~mm}$ and $7.8^{\circ} \mathrm{C}$ and $626 \mathrm{~mm}$ at Jyndevad, Foulum and Flakkebjerg, respectively.

\subsection{Experimental treatments}

The long-term experiment was initiated in 1997 with a factorial design and three factors: use or not of catch crops $(+\mathrm{CC} /-\mathrm{CC})$; use or not of manure $(+\mathrm{M} /-\mathrm{M})$, and use of legume crops in the rotations $(02 / 04)$. Rotation 02 included a whole-year grass-clover green manure crop, whereas a pulse crop was grown in 04 instead of grass-clover. The twelve-year experiment period was divided into three four-year cycles (Table 1). Rotation $\mathrm{O} 2$ was established at all three locations, while rotation $\mathrm{O} 4$ was not initially set up at Jyndevad. However, from 2005, rotation 04 was also established at Jyndevad, and in both, $\mathrm{O} 2$ and $\mathrm{O} 4$, and at all three sites the $-\mathrm{CC} /-\mathrm{M}$ treatment was not continued. Each factor combination had two replicates and all crops in the rotation were grown every year. This resulted in a total of 32-64 plots at each site depending on the rotation cycle (1-2 rotations per site $\times 4$ crops per rotation $\times 3-4$ catch crop/manure treatments $\times 2$ replicates). The plot sizes were 378 , 216 and $169 \mathrm{~m}^{2}$ at Jyndevad, Foulum and Flakkebjerg, respectively.

\subsection{Crop management}

The spring cereals grown in the crop rotations were spring barley (Hordeum vulgare L.), and spring oat (Avena sativa L.). The varieties for spring barley were Bartok or a mixture of Alexis, Henni and Lamba in the first cycle of the experiment; Ferment or a mixture of Otira, Punto and Cicero during the second cycle and a mixture of Power, Simba and Smilla or a mixture of Cicero, Simba and Smilla in the last cycle. For spring oats the varieties were Sanna and Gunhild for the first and the second cycle of the experiment, respectively. Crops were sown at a depth of $2-4 \mathrm{~cm}$ and at a row distance of $12-12.5 \mathrm{~cm}$. The sowing was done during the period from late March to the first week of May at a target density of 300 plants $\mathrm{m}^{-2}$ for spring barley and 400 plants $\mathrm{m}^{-2}$ for spring oat. Both cereals were harvested from late July to early September.

The other crops grown as main crops within the two rotations were: winter wheat (Triticum aestivum $\mathrm{L}$.), winter rye (Secale cereal L.), winter triticale (Triticosecale), lupin (Lupinus angustifolius L.), faba bean (Vicia faba L.) a mixture of pea (Pisum sativum L.) and spring barley, potato (Solanum tuberosum L.) and grass-clover, mainly including perennial ryegrass (Lolium perenne L.), white clover (Trifolium repens L.) and red clover (Trifolium pretense L.). For the first two cycles of the rotation experiment (1997-2004) the non-legume catch crop varied between monocultures of ryegrass or mixtures of ryegrass and chicory (Cichorium intybus L.) undersown in spring. The legume catch crop varied between stands of sole white clover, mixtures of ryegrass and four clover species undersown with pea/barley (black medic Medicago lupulina L., trefoil Lotus corniculatus L., serradella Ornithopus sativus Broth. and subterranean clover Trifolium subterraneum L.), mixtures of ryegrass, chicory, black medic and kidney vetch (Anthyllis vulneraria L.) 
Table 1

Structure of the crop rotations $\mathrm{O} 2$ and $\mathrm{O} 4$ during the three cycles of the experiment from 1997 to 2008.

\begin{tabular}{|c|c|c|c|c|c|c|c|}
\hline \multirow{2}{*}{$\begin{array}{l}\text { Crop rotations } \\
\text { Cycle }\end{array}$} & \multirow[t]{2}{*}{ Field no. } & \multicolumn{3}{|l|}{$\mathrm{O} 2$} & \multicolumn{3}{|l|}{$\mathrm{O} 4$} \\
\hline & & Crop & $M^{a}$ & $\mathrm{CC}^{\mathrm{b}}$ & Crop & $M^{\mathrm{a}}$ & $\mathrm{CC}^{\mathrm{b}}$ \\
\hline \multirow[t]{4}{*}{ 1st cycle (1997-2000) } & 1 & S. barley:ley & 50 & & Spring oat & 40 & $+^{e}$ \\
\hline & 2 & Grass-clover & 0 & & Winter wheat & 70 & $+^{e}$ \\
\hline & 3 & Winter wheat & 50 & $+c$ & Winter cereal & 70 & $+e$ \\
\hline & 4 & Pea/barley & 0 & $++^{d}$ & Pea/barley & 0 & $++^{d}$ \\
\hline \multirow[t]{4}{*}{ 2nd cycle (2001-2004) } & 1 & S. barley:ley & 50 & & Winter wheat & 50 & $+^{d}$ \\
\hline & 2 & Grass-clover & 0 & & Spring oat & 50 & $++^{d}$ \\
\hline & 3 & Winter cereal & 50 & $+^{c}$ & S. barley & 50 & $+^{c}$ \\
\hline & 4 & Lupin & 0 & $+^{d}$ & Lupin & 0 & \\
\hline Locations & & FO, JY, FL & & & $\mathrm{FO}, \mathrm{FL}$ & & \\
\hline \multirow[t]{4}{*}{ 3rd cycle (2005-2008) } & 1 & S. barley:ley & 60 & & S. barley & 60 & $++^{d}$ \\
\hline & 2 & Grass-clover & 0 & & Faba bean & 0 & $+d$ \\
\hline & 3 & Potato & 110 & & Potato & 110 & \\
\hline & 4 & Winter wheat & 110 & $+^{d}$ & Winter wheat & 110 & $++^{d}$ \\
\hline Locations & & FO, JY, FL & & & FO, JY, FL & & \\
\hline
\end{tabular}

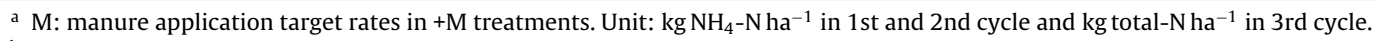

b CC: crops succeeded by catch crops in +CC treatments.

c Monocultures or mixtures of non- $\mathrm{N}_{2}$-fixing catch crops.

d Mixtures of $\mathrm{N}_{2}$-fixing and non- $\mathrm{N}_{2}$-fixing catch crops.

e White clover.

undersown in lupin, and a mixture of ryegrass with white and red clover undersown in winter wheat and spring oat. In the last cycle of the experiment (2005-2008) a mixture of perennial ryegrass, chicory, white clover and red clover was undersown in the main crops in spring, or a mixture of winter vetch, winter rye and winter rape (Brassica napus L.), with or without ryegrass, was sown after harvest of the main crop at Foulum and Jyndevad. At Flakkebjerg the catch crop mixture was composed mainly of winter rye, winter vetch and oil radish (Raphanus sativus L) sown after harvest of the main crop. Catch crops were sown after harvest when there was a need to control perennial weeds by stubble cultivation and harrowing in autumn. Differences in the duration of the development period between catch crops undersown in spring or sown after harvest were taken into account when analyzing the response of crop DM yield on catch crop N with a "resowing" factor (see statistical analyses section). Catch crops sown after harvest were considered as "resown +" and those undersown in spring as "resown -". Catch crops were incorporated in the soil by ploughing in spring (Foulum and Jyndevad) or early winter (Flakkebjerg).

All crop residues were left on the ground or incorporated into the soil after harvest. Cuttings of grass-clover in the 02 rotation (2-5 per season) were left on the soil in all treatments, except in the manured treatments in the third cycle of the experiment. Weeds were controlled in all rotations by mechanical weed harrowing (tine harrowing in cereals and pulses and ridging in potatoes). Plots with perennial weeds were harrowed in autumn in the -CC treatments and in some years in the $+\mathrm{CC}$ treatments immediately after harvest. In this last case catch crops were sown after completion of the weed harrowings.

Irrigation of spring cereals was applied at Jyndevad in order to avoid critical water deficits during the growing season. At Foulum irrigation was done only during the third cycle of the rotation. No irrigation was supplied to spring cereals at Flakkebjerg. The manure application in the $+\mathrm{M}$ treatments to the different crops in rotation is shown in Table 1 . The $\mathrm{N}$ rates supplied to cereals aimed in the first two cycles to provide $40 \%$ of the recommended $\mathrm{N}$ rates in conventional farming in Denmark (Plantedirektoratet, 1997). In the third cycle of the experiment these values were updated following new standards on the maximum allowed levels of $\mathrm{N}$ in animal manure from non-organic farming that can be imported in organic farming (Plantedirektoratet, 2005). Anaerobically stored cattle slurry at Jyndevad, pig slurry at Foulum and biogas digested slurry at Flakkebjerg were used as manure in the first two cycles, and anaerobically stored pig slurry in the last rotation cycle. Analysis of slurry samples confirmed that the actual rates of $\mathrm{N}$ applied were close to the target levels.

\subsection{Measurements}

Grain yields of the cereal crops were determined at harvest in the $\mathrm{O} 2$ and $\mathrm{O} 4$ rotations in two subplots of $22.5,24$ and $16 \mathrm{~m}^{2}$ per plot at Jyndevad, Foulum and Flakkebjerg, respectively. Grain dry matter and $\mathrm{N}$ content were analyzed on a bulked sample for each plot either by the Dumas method (Hansen, 1989) or by near infrared transmittance (NIT) (Buchmann et al., 2001). Aboveground biomass samples in autumn (about 1st November) were taken in two subplots of $0.5 \mathrm{~m}^{2}$ at a height of $1-2 \mathrm{~cm}$ for determination of dry weight and N content using the Dumas method. Similar samplings of the grass-clover green manure in autumn (from midSeptember to early November) after the harvest of spring barley and at the time of the first cutting in spring (from May to early June) were performed in the $\mathrm{O} 2$ rotation. In these samples ryegrass and clover were separated prior to analysis of DM and $\mathrm{N}$ content. At Foulum, during 2000, above-ground biomass samples were also taken every two weeks from sowing to harvest of spring barley in the $\mathrm{O} 2$ rotation.

\subsection{Statistical analyses}

Analyses of treatment effects were carried out using the procedure Mixed of SAS (SAS Institute, 2008). For analyses of variance (Tables 2 and 4 ) the analyses were carried out for each location and cycle of the experiment separately using a mixed model with fixed effects of rotation, manure and catch crop and their interactions and with random effects of block. The analysis of response of catch crop $\mathrm{N}$ on crop grain $\mathrm{N}$ uptake (Table 5 ) was carried out initially using a mixed model with fixed effects of crop, location, manure, rotation and the interactions of crop, location, manure and rotation with catch crop $\mathrm{N}$, and with random effects of year and the interaction of block and location. The analysis of response of crop DM yield on catch crop N (Table 5) was carried out initially using a mixed model with fixed effects of crop, location, manure, rotation and resowing of the catch crop, the two-way interactions of manure and rotation with cereal DM grain yield and the three-way interaction of crop 
Table 2

Mean dry matter and $\mathrm{N}$ yield of spring oat for the first (1997-2000) and second (2001-2004) cycles of the experiment.

\begin{tabular}{|c|c|c|c|c|c|}
\hline \multirow[t]{2}{*}{ Location } & \multirow[t]{2}{*}{ Treatment } & \multicolumn{2}{|c|}{ Dry matter yield (Mg DM ha ${ }^{-1}$ ) } & \multicolumn{2}{|c|}{$\mathrm{N}$ yield $\left(\mathrm{kg} \mathrm{N} \mathrm{ha}^{-1}\right)$} \\
\hline & & Cycle 1 & Cycle $2^{\mathrm{a}}$ & Cycle 1 & Cycle $2^{\mathrm{a}}$ \\
\hline \multirow[t]{4}{*}{ Foulum } & $\mathrm{O} 4 /-\mathrm{CC} /-\mathrm{M}$ & $3.5 \mathrm{a}$ & $3.4 \mathrm{a}$ & $54 \mathrm{a}$ & $49 a$ \\
\hline & $\mathrm{O} 4 /-\mathrm{CC} /+\mathrm{M}$ & $4.4 \mathrm{~b}$ & $5.0 \mathrm{~b}$ & $70 \mathrm{~b}$ & $71 \mathrm{~b}$ \\
\hline & $\mathrm{O} 4 /+\mathrm{CC} /-\mathrm{M}$ & $3.7 \mathrm{a}$ & $5.2 \mathrm{bc}$ & $55 \mathrm{a}$ & $86 c$ \\
\hline & $\mathrm{O} 4 /+\mathrm{CC} /+\mathrm{M}$ & $4.7 \mathrm{~b}$ & $5.6 \mathrm{c}$ & $76 \mathrm{~b}$ & $101 \mathrm{~d}$ \\
\hline \multirow[t]{4}{*}{ Flakkebjerg } & $\mathrm{O} 4 /-\mathrm{CC} /-\mathrm{M}$ & $2.4 \mathrm{a}$ & $2.0 \mathrm{a}$ & $36 a$ & $28 \mathrm{a}$ \\
\hline & $\mathrm{O} 4 /-\mathrm{CC} /+\mathrm{M}$ & $3.2 \mathrm{ab}$ & $4.0 \mathrm{~b}$ & $47 \mathrm{a}$ & $58 \mathrm{~b}$ \\
\hline & $\mathrm{O} 4 /+\mathrm{CC} /-\mathrm{M}$ & $2.8 \mathrm{a}$ & $4.4 \mathrm{~b}$ & $40 \mathrm{a}$ & $67 \mathrm{bc}$ \\
\hline & $\mathrm{O} 4 /+\mathrm{CC} /+\mathrm{M}$ & $3.9 \mathrm{~b}$ & $4.9 \mathrm{~b}$ & $60 \mathrm{~b}$ & $81 \mathrm{c}$ \\
\hline
\end{tabular}

Values with the same letter within a column for each location are not significantly different $(P<0.05)$.

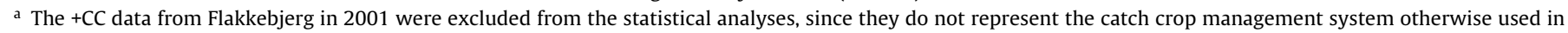
the experiment (see Fig. 1 caption).

and location with cereal DM grain yield and with random effects of year and the interaction of block and location. For the estimation of model parameters (Tables 6 and 7) these models were reduced by excluding non-significant fixed effects. The General Linear Model (GLM) procedure of SAS was applied for analysis of variance and the Duncan's multiple range test $(P<0.05)$ for the significance of mean observation differences of clover biomass at the first cutting (Table 8).

\section{Results}

\subsection{Grain dry matter and $N$ yield at harvest}

Spring oat in the $\mathrm{O} 4$ rotation tended to have higher yields when the crop was grown in systems receiving manure and included catch crops (Fig. 1). The presence of catch crops increased spring oat grain DM and $\mathrm{N}$ yield in both manured and unmanured treatments at Foulum and Flakkebjerg. The increases in yield ranged from 0.2 to $2.4 \mathrm{MgDM} \mathrm{ha}^{-1}$ and from 1 to $39 \mathrm{~kg} \mathrm{Nha}^{-1}$ depending on manure application and site, when averaging per rotation cycle (Table 2). This beneficial effect of catch crops was highest in the unmanured treatment and during the second cycle of the rotation, being in this case comparable to the effect of manure or even larger as found in grain $\mathrm{N}$ yield at Foulum (Table 2). At this site catch crop $\mathrm{N}$ in the autumn before oats was significantly higher during the second rotation cycle (Table 3). Oat yield fluctuations responded also to weather conditions, especially at Flakkebjerg. For example at this site, the highest yields observed in 2003 corresponded to a growing season with a mean temperature and precipitation (April-July) that was $1.4{ }^{\circ} \mathrm{C}$ and $28 \mathrm{~mm}$ above average. On the other hand, the driest conditions were recorded in 2001 at Flakkebjerg, with 36\% less precipitation in the May-June period, resulting in low yields at this site. The growing season (April-July) was on average 0.4 and $0.6^{\circ} \mathrm{C}$ warmer during the second rotation cycle at Foulum and Flakkebjerg, respectively. For any given

\section{Table 3}

Average, maximum and minimum catch crop $\mathrm{N}\left(\mathrm{kg} \mathrm{Nha}^{-1}\right)$ in autumn before oats for the first (1997-2000) and the second cycle (2001-2004) of the experiment in the rotation $\mathrm{O} 4$ with and without manure.

\begin{tabular}{llll}
\hline Location & Mean & Max. & Min. \\
\hline Foulum & & & \\
Cycle 1 & $35 \mathrm{a}$ & 47 & 23 \\
Cycle 2 & $59 \mathrm{~b}$ & 93 & 14 \\
Flakkebjerg & & & \\
Cycle 1 & $24 \mathrm{a}$ & 44 & 10 \\
Cycle 2 & $30 \mathrm{a}$ & 41 & 9 \\
\hline
\end{tabular}

Values with the same letter within a location are not significantly different $(P<0.05)$. treatment, spring oat yield was larger at Foulum than at Flakkebjerg (averaging all treatments this difference was $1.0 \mathrm{Mg} \mathrm{DM} \mathrm{ha}^{-1}$ and $18 \mathrm{~kg} \mathrm{Nha}^{-1}$ in the first cycle and in the second cycle). Yields showed a tendency to increase over time except in the unmanured systems without catch crops. The trend was particularly pronounced in the treatment without manure and with catch crops.

Spring barley in rotation $\mathrm{O} 4$ generally showed considerable DM and $\mathrm{N}$ yield benefits from using catch crops with manure application at all sites (Fig. 2). The unmanured treatments were also improved with catch crops although the available data for comparison is only for Foulum and Flakkebjerg and the period 2001-2004. The average effect ranged from 0.2 to $1.4 \mathrm{Mg} \mathrm{DM} \mathrm{ha}^{-1}$ and from 10 to $27 \mathrm{~kg} \mathrm{~N} \mathrm{ha}^{-1}$ depending on manure application, site and rotation cycle (Table 4). As for spring oat, in the second cycle of the rotation the effect of catch crop was close to that of application of manure, although this varied between years (Fig. 2). For the third cycle of the rotation differences in relative effect of manure and catch crop on yields were found among locations. At Jyndevad and Flakkebjerg manure increased spring barley yields more than catch crops. However, at Foulum, a reduction on yields was observed for the last two years in the system without catch crops that was not observed in the catch crop systems. This resulted in a similar average yield effect of catch crops compared to manure for the last experimental cycle at Foulum (Table 4).

In contrast to $\mathrm{O} 4$, in the $\mathrm{O} 2$ rotations the application of manure was always the main factor affecting spring barley grain yields at all three locations (Fig. 3). The positive effect of catch crops in $\mathrm{O} 2$ was in general much lower than in the 04 rotation. This effect was higher at Jyndevad $\left(0.6 \mathrm{Mg} \mathrm{ha}^{-1}\right.$ and $10 \mathrm{~kg} \mathrm{Nha}^{-1}$ on average), especially in the manured treatment of the last cycle where it reached $1.5 \mathrm{Mg} \mathrm{ha}^{-1}$ and $25 \mathrm{~kg} \mathrm{~N} \mathrm{ha}^{-1}$, and almost null at Flakkebjerg (Table 4). At Foulum the catch crop effect on yield averaged $0.3 \mathrm{Mg} \mathrm{DM} \mathrm{ha}^{-1}$ and $6 \mathrm{~kg} \mathrm{Nha}^{-1}$ when pooling treatments and rotation cycles, and it was lowest in the manured treatment of the second cycle. Overall yields were more stable between years at Flakkebjerg, where grain DM and $\mathrm{N}$ yield were in most of the years between 3 and $4 \mathrm{Mg} \mathrm{ha}^{-1}$, and 45 and $60 \mathrm{~kg} \mathrm{~N} \mathrm{ha}^{-1}$, respectively, in the treatments with manure and between 2 and $3 \mathrm{Mg} \mathrm{ha}^{-1}$ and 25 and $40 \mathrm{~kg} \mathrm{Nha}^{-1}$ in the unmanured systems. The yields at Jyndevad and Foulum showed a higher variability between years with a tendency to increase in the third cycle of the experiment.

\subsection{Relation between $N$ in catch crops and $N$ harvested in grain}

The amount of $\mathrm{N}$ in the harvested grain of cereal crops and in the November catch crop samples was significantly affected by location (Table 5). Crop type and manure application also influenced grain $\mathrm{N}$ yield but not catch crop $\mathrm{N}$ that in turn depended 


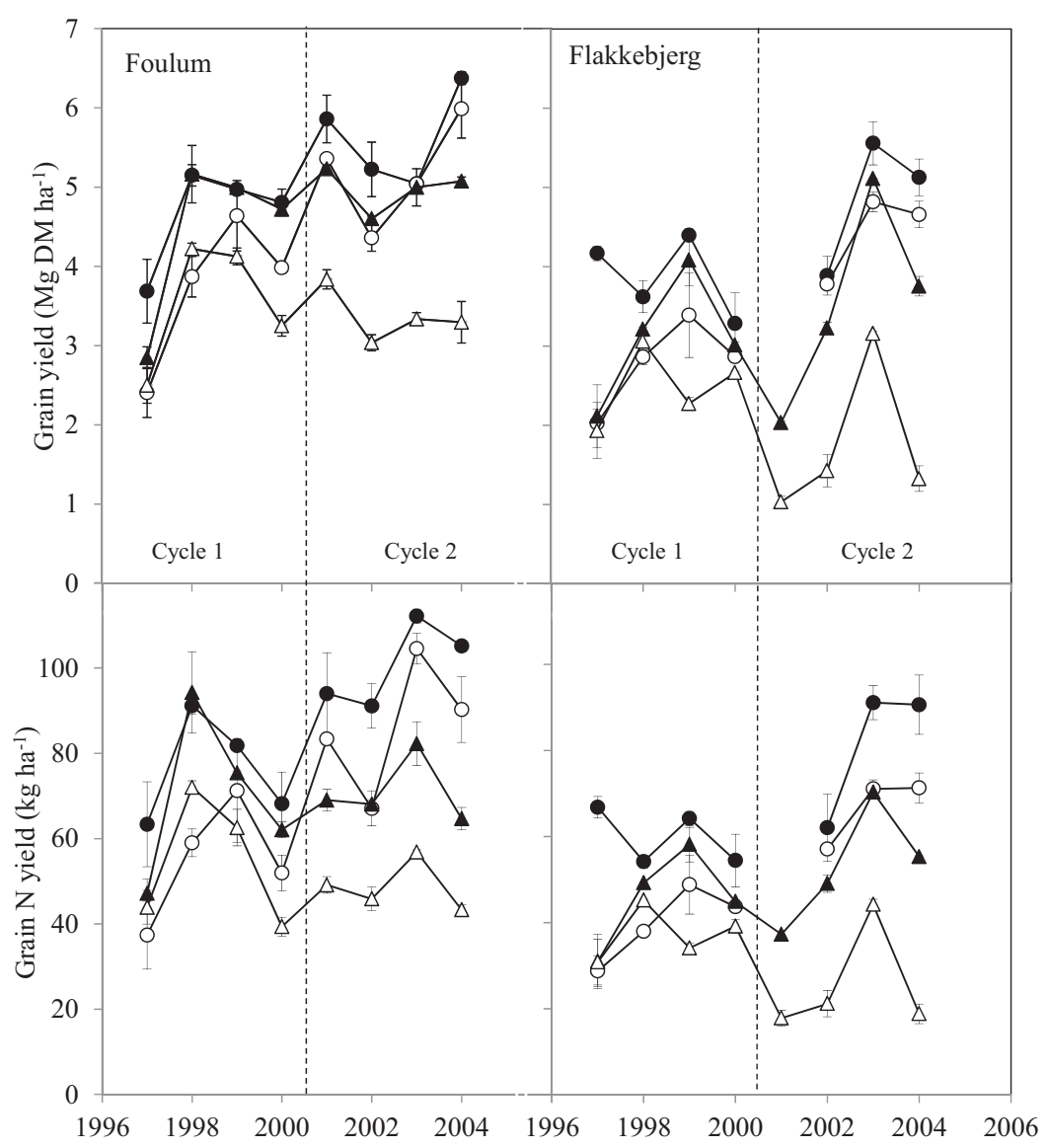

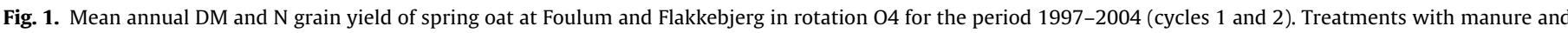

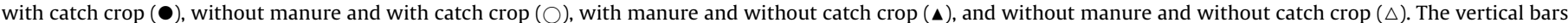

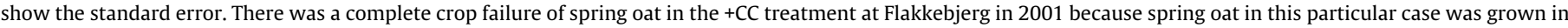
a permanent stand of white clover, a system called oat:clover bi-cropping (Thorsted et al., 2002).

Table 4

Mean dry matter and N yield in spring barley for the three cycles (cycle 1: 1997-2000, cycle 2: 2000-2004, cycle 3: 2005-2008) of the experiment.

\begin{tabular}{|c|c|c|c|c|c|c|c|c|c|c|c|c|c|}
\hline \multirow{3}{*}{$\begin{array}{l}\text { Location } \\
\text { Jyndevad }\end{array}$} & \multirow{3}{*}{$\begin{array}{l}\text { Treatment } \\
\mathrm{O} 2 /-\mathrm{CC} /-\mathrm{M}\end{array}$} & \multicolumn{6}{|c|}{ Dry matter yield (Mg DM ha ${ }^{-1}$ ) } & \multicolumn{6}{|c|}{$\mathrm{N}$ yield $\left(\mathrm{kg} \mathrm{N} \mathrm{ha}^{-1}\right)$} \\
\hline & & \multicolumn{2}{|c|}{ Cycle 1} & \multicolumn{2}{|c|}{ Cycle 2} & \multicolumn{2}{|c|}{ Cycle 3} & \multicolumn{2}{|c|}{ Cycle 1} & \multicolumn{2}{|c|}{ Cycle 2} & \multicolumn{2}{|c|}{ Cycle 3} \\
\hline & & 1.6 & $\mathrm{a}$ & 2.1 & $\mathrm{a}$ & & & 23 & $\mathrm{a}$ & 29 & $\mathrm{a}$ & & \\
\hline & $\mathrm{O} 2 /-\mathrm{CC} /+\mathrm{M}$ & 2.5 & $\mathrm{~b}$ & 3.3 & $\mathrm{~b}$ & 3.2 & bef & 33 & $a b$ & 43 & $\mathrm{~b}$ & 44 & $\mathrm{~b}$ \\
\hline & $\mathrm{O} 2 /+\mathrm{CC} /-\mathrm{M}$ & 2.2 & $a b$ & 2.0 & $\mathrm{a}$ & 2.6 & ad & 29 & $\mathrm{a}$ & 26 & $\mathrm{a}$ & 36 & $a b$ \\
\hline & $\mathrm{O} 2 /+\mathrm{CC} /+\mathrm{M}$ & 3.0 & c & 3.9 & $\mathrm{~b}$ & 4.7 & c & 42 & b & 57 & $\mathrm{~b}$ & 69 & c \\
\hline & $\mathrm{O} 4 /-\mathrm{CC} /+\mathrm{M}$ & & & & & 3.2 & ed & & & & & 42 & $\mathrm{ab}$ \\
\hline & $\mathrm{O} 4 /+\mathrm{CC} /-\mathrm{M}$ & & & & & 2.4 & $a b$ & & & & & 33 & $a b$ \\
\hline & $\mathrm{O} 4 /+\mathrm{CC} /+\mathrm{M}$ & & & & & 4.3 & fc & & & & & 63 & $\mathrm{c}$ \\
\hline \multirow[t]{8}{*}{ Foulum } & $\mathrm{O} 2 /-\mathrm{CC} /-\mathrm{M}$ & 2.8 & $\mathrm{a}$ & 3.2 & $\mathrm{a}$ & & & 36 & $\mathrm{a}$ & 48 & $\mathrm{a}$ & & \\
\hline & $\mathrm{O} 2 /-\mathrm{CC} /+\mathrm{M}$ & 3.8 & $\mathrm{~b}$ & 4.5 & $\mathrm{c}$ & 4.7 & $\mathrm{ab}$ & 52 & b & 69 & $\mathrm{~b}$ & 71 & abc \\
\hline & $\mathrm{O} 2 /+\mathrm{CC} /-\mathrm{M}$ & 3.1 & $\mathrm{a}$ & 3.5 & $a b$ & 4.3 & $a b$ & 41 & $\mathrm{a}$ & 52 & $\mathrm{a}$ & 68 & ac \\
\hline & $\mathrm{O} 2 /+\mathrm{CC} /+\mathrm{M}$ & 4.4 & $\mathrm{~b}$ & 4.3 & c & 5.0 & $\mathrm{~b}$ & 62 & $\mathrm{~b}$ & 69 & $\mathrm{~b}$ & 84 & $\mathrm{~b}$ \\
\hline & $\mathrm{O} 4 /-\mathrm{CC} /-\mathrm{M}$ & & & 2.4 & $\mathrm{~d}$ & & & & & 36 & c & & \\
\hline & $\mathrm{O} 4 /-\mathrm{CC} /+\mathrm{M}$ & & & 3.6 & $\mathrm{ab}$ & 3.9 & $\mathrm{a}$ & & & 53 & ad & 56 & $\mathrm{a}$ \\
\hline & $\mathrm{O} 4 /+\mathrm{CC} /-\mathrm{M}$ & & & 3.8 & $\mathrm{~b}$ & 3.9 & $\mathrm{a}$ & & & 63 & bd & 57 & $\mathrm{a}$ \\
\hline & $\mathrm{O} 4 /+\mathrm{CC} /+\mathrm{M}$ & & & 4.5 & c & 5.0 & $\mathrm{~b}$ & & & 77 & $\mathrm{~b}$ & 80 & bc \\
\hline \multirow[t]{8}{*}{ Flakkebjerg } & $\mathrm{O} 2 /-\mathrm{CC} /-\mathrm{M}$ & 2.0 & $\mathrm{a}$ & 2.7 & $\mathrm{a}$ & & & 26 & $\mathrm{a}$ & 39 & $\mathrm{a}$ & & \\
\hline & $\mathrm{O} 2 /-\mathrm{CC} /+\mathrm{M}$ & 3.2 & $\mathrm{~b}$ & 3.7 & $\mathrm{~b}$ & 3.3 & $a b c$ & 41 & b & 54 & bc & 52 & $\mathrm{~b}$ \\
\hline & $\mathrm{O} 2 /+\mathrm{CC} /-\mathrm{M}$ & 2.1 & $\mathrm{a}$ & 3.0 & $a$ & 2.8 & $\mathrm{ab}$ & 27 & $\mathrm{a}$ & 43 & $a$ & 39 & $\mathrm{a}$ \\
\hline & $\mathrm{O} 2 /+\mathrm{CC} /+\mathrm{M}$ & 3.4 & $\mathrm{~b}$ & 3.8 & $\mathrm{~b}$ & 3.6 & $\mathrm{c}$ & 44 & b & 62 & c & 55 & $\mathrm{~b}$ \\
\hline & $\mathrm{O} 4 /-\mathrm{CC} /-\mathrm{M}$ & & & 1.7 & c & & & & & 25 & $\mathrm{~d}$ & & \\
\hline & $\mathrm{O} 4 /-\mathrm{CC} /+\mathrm{M}$ & & & 3.4 & bd & 3.0 & bc & & & 49 & $a b$ & 43 & $a b$ \\
\hline & $\mathrm{O} 4 /+\mathrm{CC} /-\mathrm{M}$ & & & 3.1 & ad & 2.4 & $\mathrm{a}$ & & & 48 & $a b$ & 34 & $\mathrm{a}$ \\
\hline & $\mathrm{O} 4 /+\mathrm{CC} /+\mathrm{M}$ & & & 3.6 & $\mathrm{~b}$ & 3.6 & c & & & 63 & $\mathrm{c}$ & 53 & $\mathrm{~b}$ \\
\hline
\end{tabular}

Values with the same letter within a column for each location are not significantly different $(P<0.05)$. 


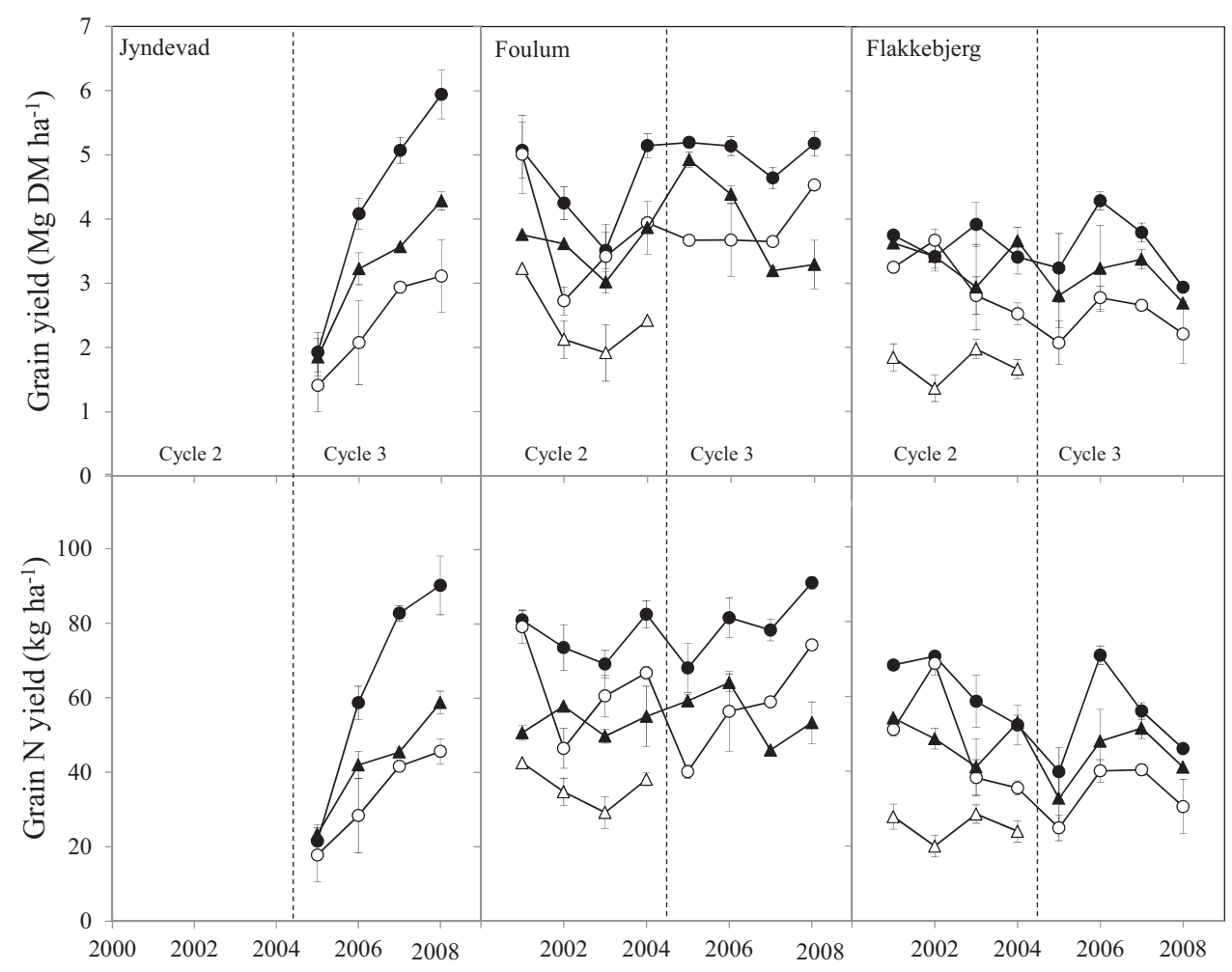

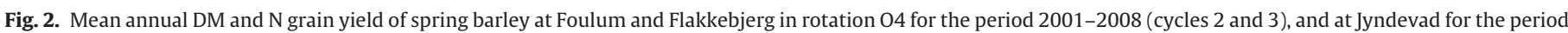

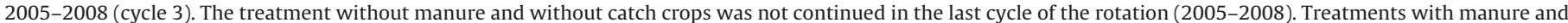

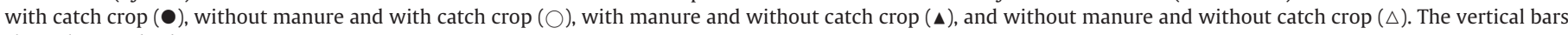
show the standard error.

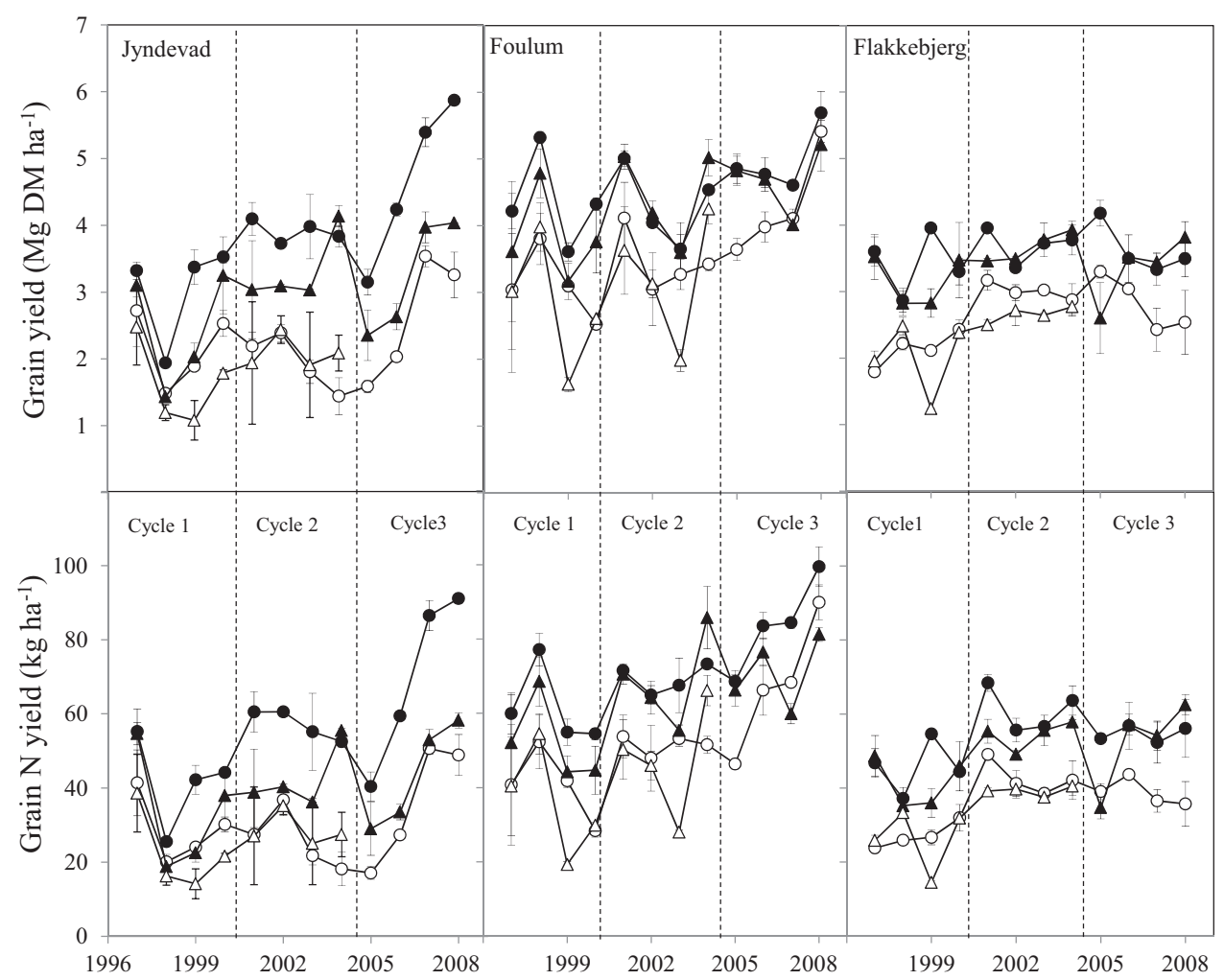

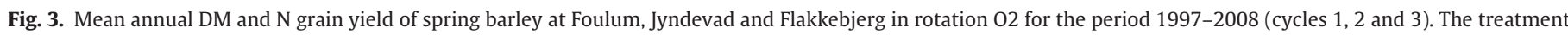

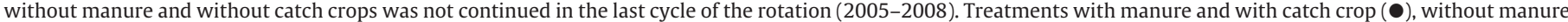
and with catch crop $(\bigcirc)$, with manure and without catch crop $(\Delta)$, and without manure and without catch crop $(\Delta)$. The vertical bars show the standard error. 
Table 5

Probability values of the factors crop type (Crop), site (Location), manure application (Manure), crop rotation (Rotation) and resowing of the catch crop after harvest (Resown) on cereal crop $\mathrm{N}$ uptake (Crop_N) and catch crop N uptake (CC_N), and on the interactions of previous catch crop $\mathrm{N}\left(\mathrm{CC}_{\mathrm{p}} \mathrm{N}\right)$ on crop $\mathrm{N}$ (Crop_N) and of dry matter yield of the preceding crop (DM_Y) on catch crop N (CC_N).

\begin{tabular}{|c|c|c|}
\hline Effect & Crop_N & CC_N \\
\hline Crop & ${ }^{* *}$ & NS \\
\hline Location & ** & \\
\hline Manure & $* * *$ & NS \\
\hline Rotation & NS & NS \\
\hline Resown & & $* * *$ \\
\hline $\mathrm{CC}_{\mathrm{p}-\mathrm{N}} \times$ Crop & ${ }^{* *}$ & \\
\hline $\mathrm{CC}_{\mathrm{p}-\mathrm{N}} \times$ Location & $* * *$ & \\
\hline $\mathrm{CC}_{\mathrm{p}-\mathrm{N}} \times$ Manure & NS & \\
\hline $\mathrm{CC}_{\mathrm{p}-\mathrm{N}} \times$ Rotation & NS & \\
\hline DM_Y × Manure & & NS \\
\hline DM_Y $\times$ Rotation & & NS \\
\hline DM_Y $\times$ Resown & & \\
\hline $\mathrm{DM}_{-} \mathrm{Y} \times$ Crop $\times$ Location & & $* * *$ \\
\hline $\begin{array}{l}\text { Significance levels: NS: } P> \\
{ }^{*} 0.05>P>0.01 . \\
{ }^{* *} 0.01>P>0.001 . \\
0.001>P .\end{array}$ & & \\
\hline
\end{tabular}

on whether or not the catch crop mixture was resown after the harvest of main crop. The effect of $\mathrm{N}$ in catch crop biomass on $\mathrm{N}$ grain yield of the following spring cereal was found to interact with crop type and location but not with manure or rotation (Table 5). Crop $\mathrm{N}$ yield was significantly higher in spring oats than in spring barley and at Foulum than at Jyndevad or Flakkebjerg, when analyzing all the systems that included catch crops (Table 6). The average catch crop $\mathrm{N}$ was almost twice as high at Foulum $\left(40 \mathrm{~kg} \mathrm{Nha}^{-1}\right)$ than at Jyndevad or Flakkebjerg $\left(22 \mathrm{~kg} \mathrm{~N} \mathrm{ha}^{-1}\right)$. The statistical model showed a higher apparent $\mathrm{N}$-recovery efficiency $\left(N_{\text {rec }}\right)$ from catch crops in spring oats $\left(0.69 \mathrm{~kg} \mathrm{~kg}^{-1} \mathrm{~N}\right)$ than in spring barley $\left(0.46 \mathrm{~kg} \mathrm{~kg}^{-1} \mathrm{~N}\right)$ (Table 7). The recovery of $\mathrm{N}$ from catch crops in grain yield was found to be higher at Jyndevad than at Foulum or Flakkebjerg.

\subsection{Competition between cereals and undersown green manure or catch crops}

The amount of $\mathrm{N}$ in catch crops was higher when the catch crop was undersown $\left(31 \mathrm{~kg} \mathrm{~N} \mathrm{ha}^{-1}\right)$ compared to when it was sown $\left(\right.$ resown + ) after harvest $\left(25 \mathrm{~kg} \mathrm{~N} \mathrm{ha}^{-1}\right)$ (Table 6). The catch crop $\mathrm{N}$ was further affected by competition between cash crop and the undersown catch crops as shown by the effect of crop DM yield on catch crop N (Tables 5 and 7). Manure or rotation did not significantly affect this relationship, but significant interactions between crop dry matter yield and crop and location on catch crop $\mathrm{N}$ were

\section{Table 6}

Least square means of fixed effects in statistical analyses of crop $\mathrm{N}$ uptake (Crop_N) $\left(\mathrm{kg} \mathrm{Nha}^{-1}\right)$ and catch crop $\mathrm{N}\left(\mathrm{CC}_{\mathrm{p}} \mathrm{N}\right)\left(\mathrm{kg} \mathrm{Nha}^{-1}\right)$ using a mixed model with fixed effects of crop type (Crop), site (Location), manure application (Manure, $+/-$ ) and resowing of the catch crop (Resown, $+/-$ ). Only the variables with significant effects from Table 5 were included in the model. Values in brackets are the standard error of the estimates.

\begin{tabular}{llll}
\hline Effect & Factor & Crop_N & CC $_{\mathrm{p} \_N}$ \\
\hline Crop & S. barley & $52(2.9)$ & \\
& S. oat & $70(3.2)$ & \\
Location & Jyndevad & $53(3.6)$ & $22(2.7)$ \\
& Foulum & $71(3.5)$ & $40(2.4)$ \\
& Flakkebjerg & $59(3.5)$ & $22(2.3)$ \\
Manure & - & $52(3.0)$ & \\
& + & $71(3.0)$ & \\
Resown & - & & $31(2.3)$ \\
& + & & $25(2.6)$ \\
\hline
\end{tabular}

Table 7

Apparent N-recovery efficiency from catch crops $\left(N_{\text {rec }}\right)$ and nitrogen cost in catch crops $\left(N_{c}\right)$ through linear regressions of crop $\mathrm{N}$ uptake (Crop_N) on previous catch crop $\mathrm{N}\left(\mathrm{CC}_{\mathrm{p}_{-}} \mathrm{N}\right)$ and of catch crop $\mathrm{N}\left(\mathrm{CC}_{-} \mathrm{N}\right)$ on dry matter yield of the preceding crop (DM_Y), respectively. The mixed model included fixed effects of crop type (Crop), site (Location) and resowing of the catch crop (Resown, $+1-$ ). Only the variables with significant effects from Table 5 were considered in the model. Values in brackets are the standard error of the estimates.

\begin{tabular}{|c|c|c|}
\hline Effect & Factor & \\
\hline \multicolumn{2}{|l|}{ Crop_N } & $N_{\text {rec }} \mathrm{kg} \mathrm{kg}^{-1} \mathrm{~N}$ \\
\hline \multirow[t]{2}{*}{$\mathrm{CC}_{\mathrm{p}-\mathrm{N}} \times$ Crop } & S. barley & $0.46(0.07)$ \\
\hline & S. oat & $0.69(0.10)$ \\
\hline \multirow{3}{*}{$\mathrm{CC}_{\mathrm{p}-\mathrm{N}} \times$ Location $^{\mathrm{a}}$} & Jyndevad & $0.23(0.10)$ \\
\hline & Foulum & $-0.24(0.08)$ \\
\hline & Flakkebjerg & 0.00 \\
\hline \multicolumn{2}{|l|}{$\mathrm{CC} \_\mathrm{N}$} & $N_{c} \mathrm{~kg} \mathrm{~N} \mathrm{Mg}^{-1} \mathrm{DM}$ \\
\hline \multirow[t]{2}{*}{ DM_Y $\times$ Resown } & - & $-2.8(0.85)$ \\
\hline & + & $-0.4(0.98)$ \\
\hline \multirow[t]{12}{*}{ DM_Y $\times$ Crop $\times$ Location $^{\mathrm{b}}$} & S. oat, Jyndevad ${ }^{c}$ & $1.7(2.00)$ \\
\hline & S. oat, Foulum & $-3.9(1.10)$ \\
\hline & S. oat, Flakkebjerg & $-1.4(0.79)$ \\
\hline & Pulses, Jyndevad & $-2.0(1.38)$ \\
\hline & Pulses, Foulum & $-4.2(1.27)$ \\
\hline & Pulses, Flakkebjerg & $-0.7(0.71)$ \\
\hline & S. barley, Jyndevad & $-3.0(1.25)$ \\
\hline & S. barley, Foulum & $-3.9(1.18)$ \\
\hline & S. barley, Flakkebjerg & $-0.6(0.73)$ \\
\hline & W. cereal, Jyndevad & $-3.2(1.41)$ \\
\hline & W. cereal, Foulum & $0.0(0.01)$ \\
\hline & W. cereal, Flakkebjerg & 0.0 \\
\hline
\end{tabular}

a The estimates of $\mathrm{CC}_{\mathrm{p}} \mathrm{N} \times$ Location are biased and normalised relative to the estimate for Flakkebjerg.

b The estimates of DM_Y $\times$ Crop $\times$ Location are biased and normalised relative to winter cereal at Flakkebjerg.

c Data only for 2005.

found. Where the catch crop was sown after harvest of the cash crop there was little indication of a grain yield effect on catch crop $\mathrm{N}$, whereas this was clearly present for the undersown catch crop. There was in most cases, regardless of cash crop type or location, a negative slope of the regression of cash crop grain yield on $\mathrm{N}$ uptake in the undersown catch crop $\left(N_{c}\right)$, indicating that competition affected catch crop $\mathrm{N}$ (Table 7). The size of the effect depended on location and main crop. The greatest competition effects were observed at Foulum for spring cereals and pulses and at Jyndevad for winter cereals. Spring oat and spring barley showed a similar competition with undersown crops at Foulum and Flakkebjerg, but at Jyndevad no significant competition was observed for spring oat while it was well manifested for spring barley.

The growth of grass-clover undersown with spring barley in the $\mathrm{O} 2$ rotation was differently affected by manure and catch crops at Foulum, but not at Flakkebjerg and Jyndevad (Fig. 4). The samplings performed in late autumn before the first ley cutting showed that at Foulum grass-clover grew better when spring barley received no manure. A site comparison showed a better performance of grass-clover in late autumn at Foulum for all the treatments, although it was only significant $(P<0.05)$ for the unmanured treatment. The growth of the undersown grass-clover mixture was similar at Flakkebjerg and Jyndevad in the manured and unmanured treatments.

The effect of the competition of spring barley and the undersown grass-clover was also clearly observed in the biomass of the clover fraction at the first cutting of grass-clover in the spring following the cereal (Table 8). Higher clover DM and $\mathrm{N}$ yields were found at Flakkebjerg for the unmanured treatments, although only significant $(P<0.05)$ in the $-\mathrm{CC} /-\mathrm{M}$ system. On the other hand, the lowest clover DM and $\mathrm{N}$ yields were observed at Foulum in the $+\mathrm{CC} /+\mathrm{M}$ treatment. At Jyndevad no significant differences in clover yield were found in the treatments with or without manure, although poor clover growth was observed in the $-\mathrm{CC} /-\mathrm{M}$ system. 


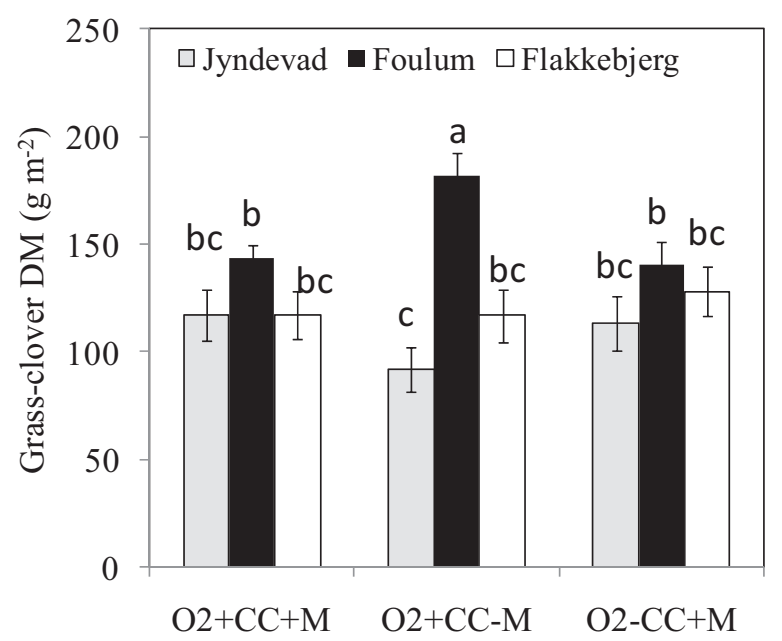

Fig. 4. Above-ground DM of the grass-clover undersown with spring barley in the $\mathrm{O} 2$ rotation in autumn (from mid-September to early November) after the harvest of the cereal and before the first cutting. Data are for the manured treatments and the unmanured one that included catch crops at the three experimental sites. Values presented are averages of the first two cycles of the rotation (1997-2004). Different letters indicate significant differences at $P<0.05$.

The analysis was also performed excluding the $-\mathrm{CC} /-\mathrm{M}$ systems to avoid potential bias for the shorter period of data for this system. The results still show significant $(P<0.05)$ higher clover yield at the unmanured system at Flakkebjerg (but not differing from the other two systems at this site) and lower yields at Foulum in the $+\mathrm{CC} /+\mathrm{M}$ treatment (but not different from the other systems at Foulum and $+\mathrm{M}$ systems at Jyndevad). In general, there was a negative relationship between yield of spring barley and clover biomass in the following grass-clover crop when pooling all the treatments at Foulum and Flakkebjerg, whereas this relation was much more variable and non-significant at Jyndevad (Fig. 5).

\subsection{Growth pattern of cereals following catch crop incorporation}

The time course of spring barley dry matter (Fig. 6a) and N uptake (Fig. 6b) in the $\mathrm{O} 2$ systems during the year 2000 at Foulum indicates that the timing of $\mathrm{N}$-availability has a large impact on crop growth. During the initial growth phase until end of May, $\mathrm{N}$ uptake was mainly affected by manure application with little effect

\section{Table 8}

Above-ground dry matter and Nyield in the clover fraction of the grass-clover grown as a green-manure in the 02 rotation at the first cutting in the spring. The values represent the average of the period 1997-2008 $(n=24)$.

\begin{tabular}{|c|c|c|c|}
\hline Location & System & $\begin{array}{l}\text { DM yield } \\
\left(\mathrm{gDM} \mathrm{m}^{-2}\right)\end{array}$ & $\begin{array}{l}\text { N yield } \\
\left(\mathrm{kgNha}^{-1}\right)\end{array}$ \\
\hline \multirow[t]{4}{*}{ Jyndevad } & $-\mathrm{CC} /-\mathrm{M}^{\mathrm{c}}$ & $166 \mathrm{~cd}$ & $53 \mathrm{~cd}$ \\
\hline & $-\mathrm{CC} /+\mathrm{M}$ & $219 \mathrm{~cd}(\mathrm{bc})^{\mathrm{b}}$ & $71 \mathrm{c}(\mathrm{b})$ \\
\hline & $+\mathrm{CC} /-\mathrm{M}$ & $231 \mathrm{c}(\mathrm{b})$ & 75 c (b) \\
\hline & $+\mathrm{CC} /+\mathrm{M}$ & $196 \mathrm{~cd}(\mathrm{bc})$ & $60 \mathrm{~cd}(\mathrm{bc})$ \\
\hline \multirow[t]{4}{*}{ Foulum } & $-\mathrm{CC} /-\mathrm{M}^{\mathrm{c}}$ & 256 bc & $80 \mathrm{bc}$ \\
\hline & $-\mathrm{CC} /+\mathrm{M}$ & $193 \mathrm{~cd}(\mathrm{bc})$ & $55 \mathrm{~cd}(\mathrm{bc})$ \\
\hline & $+\mathrm{CC} /-\mathrm{M}$ & $186 \mathrm{~cd}(\mathrm{bc})$ & $55 \mathrm{~cd}(\mathrm{bc})$ \\
\hline & $+\mathrm{CC} /+\mathrm{M}$ & $121 \mathrm{~d}(\mathrm{c})$ & $35 \mathrm{~d}(\mathrm{c})$ \\
\hline \multirow[t]{4}{*}{ Flakkebjerg } & $-\mathrm{CC} /-\mathrm{M}^{\mathrm{c}}$ & $384 a$ & $117 \mathrm{a}$ \\
\hline & $-\mathrm{CC} /+\mathrm{M}$ & $264 \mathrm{bc}(\mathrm{ab})$ & 76 c (b) \\
\hline & $+\mathrm{CC} /-\mathrm{M}$ & $344 \mathrm{ab}(\mathrm{a})$ & $104 \mathrm{ab}(\mathrm{a})$ \\
\hline & $+\mathrm{CC} /+\mathrm{M}$ & 258 bc (ab) & 75 c (b) \\
\hline
\end{tabular}

a Different letters indicate significant effect at $P<0.05$.

b Different letters in parenthesis indicate significant effect at $P<0.05$ excluding the $-\mathrm{CC} /-\mathrm{M}$ systems in the analysis.

c Values for this system are for the period 1997-2004 $(n=14)$.

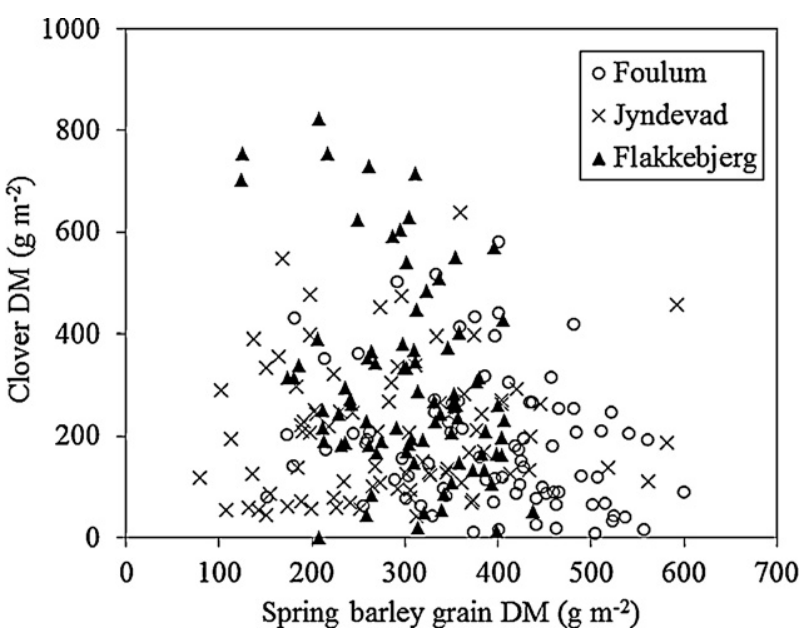

Fig. 5. Relationship between spring barley grain DM yield in the $\mathrm{O} 2$ rotation and the above-ground biomass of the clover fraction in the grass-clover green manure crop at the first cutting on the following year including the treatments $+\mathrm{M} /-\mathrm{M}$ and $+\mathrm{CC} / \mathrm{CC}$. Data is for all three cycles of the crop rotation (corresponding to the period 1997-2008). Linear regressions were: $y=-0.3088 x+304.2, r^{2}=0.06^{*}, \mathrm{df}=82$ at Foulum; $y=-0.9065 x+576.2, r^{2}=0.11^{* *}, \mathrm{df}=81$ at Flakkebjerg; $y=0.0913 x+182.8$, $r^{2}=0.01 \mathrm{~ns}, \mathrm{df}=80$ at Jyndevad. Significant levels at ${ }^{*} P<0.05$ and ${ }^{* *} P<0.01$.

of incorporation of catch crop on $\mathrm{N}$ uptake, especially in the $+\mathrm{CC} /+\mathrm{M}$ treatment. The $\mathrm{N}$ uptake rate after 1 June was $0.45 \mathrm{~kg} \mathrm{~N} \mathrm{ha}^{-1} \mathrm{~d}^{-1}$ without catch crop and $0.69 \mathrm{~kg} \mathrm{Nha}^{-1} \mathrm{~d}^{-1}$ with catch crop. This indicates a delay in availability of the $\mathrm{N}$ in catch crop, which in this case was dominated by ryegrass.
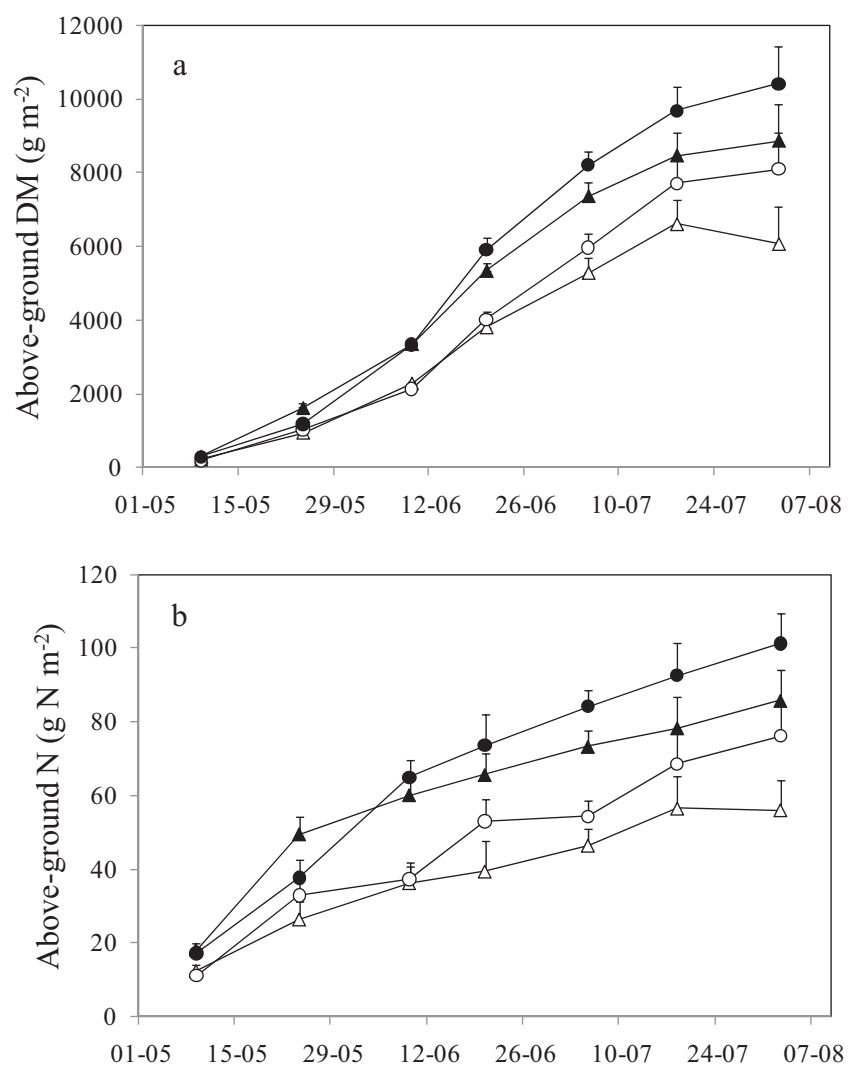

Fig. 6. Time course of above-ground DM (a) and N (b) in spring barley, weeds and grass-clover at Foulum in 2000 for the $\mathrm{O} 2$ treatments with manure and with catch $\operatorname{crop}(\bullet)$, without manure and with catch crop $(\bigcirc)$, with manure and without catch $\operatorname{crop}(\Delta)$, and without manure and without catch $\operatorname{crop}(\triangle)$. The spring barley crop was undersown with grass-clover in all treatments. The vertical bars show the standard error. 


\section{Discussion}

\subsection{Ecological intensification of spring oat}

Spring oat yields increased from the first to the second cycle of the experiment, as a result of a small increase in manure rate and possibly a change in catch crop composition, but these effects differed at Foulum and Flakkebjerg. The choice of the botanical composition of the catch crops mixture seems to have been important for increasing the $\mathrm{N}$ transfer to the spring oat crop at Foulum. In both the first and the second cycle of the rotation the mixture included ryegrass and clover species. However, the measured $\mathrm{N}$ in the above-ground biomass of catch crops, including $-\mathrm{M}$ and $+\mathrm{M}$ treatments, was significantly higher in the second rotation cycle, when white and red clover were used, with a highest value of $93 \mathrm{~kg} \mathrm{Nha}^{-1}$ (Table 3). This is almost twice that in the first cycle, when a mixture of ryegrass, black medic, trefoil, serradella and subterranean clover provided a maximum content of $47 \mathrm{~kg} \mathrm{~N} \mathrm{ha}^{-1}$. At Foulum the yield increase from the first to the second cycle due to catch crops was higher than that obtained by increasing manure $\mathrm{N}$ by $10 \mathrm{~kg} \mathrm{Nha}^{-1}$ (Table 2). The Foulum site had a fertile soil due to a prehistory of mixed farming (Olesen et al., 2007), and thus our results show that a significant improvement of organic spring oat yields can be obtained by an adequate catch crop management on these soils in a Nordic climate.

At Flakkebjerg, with low soil organic matter, the $\mathrm{N}$ in the catch crop mixtures was much lower and averaged 24 and $30 \mathrm{~kg} \mathrm{~N} \mathrm{ha}^{-1}$ for the first and the second rotation cycle, respectively (Table 3 ). This gave a lower contribution of legumes in catch crops on this soil. However, the $+\mathrm{CC}$ treatment showed a tendency for improved yields over time, which may be explained by a long-term fertility building effect of using catch crops, which was also seen by increased soil organic matter in $+\mathrm{CC}$ treatments (Schjønning et al., 2012). The overall higher catch crop effect observed at Flakkebjerg for spring oat (Table 2) is probably linked to a more limiting nutrient availability at this site together with a longer period for $\mathrm{N}$ release from mineralization of crop residues due to autumn ploughing. However, fast mineralization rates have been found even under the low winter temperatures of Nordic climates (Magid et al., 2001; Thorup-Kristensen and Dresbøll, 2010). Our results also show the importance of increasing $\mathrm{N}$ input in manure for improving yields on low soil fertility soils (Fig. 1).

The mixture of ryegrass and white and red clover seems appropriate for undersowing with spring oat as they do not compete strongly with the cereal. The reduction in catch crop $\mathrm{N}$ caused by competition with the cereal ( $\mathrm{N}$ cost, $N_{c}$ ) was estimated from the slope of the regression of grain yield on autumn catch crop $\mathrm{N}$ relative to winter cereal at Flakkebjerg (Table 7). This decrease was on average $2.7 \mathrm{~kg} \mathrm{~N} \mathrm{Mg}^{-1} \mathrm{DM}$. If assuming a $\mathrm{N}$-recovery value from catch crops of $0.69 \mathrm{~kg} \mathrm{~kg}^{-1} \mathrm{~N}$ for spring oat, the impact of $N_{c}$ on grain $\mathrm{N}$ would be lower than the benefits obtained from catch crops (Table 2). Furthermore, Askegaard et al. (2011) suggested N leaching losses to be independent from legume ratio of the catch crop mixture as also legume catch crops are able to retain $\mathrm{N}$ within the root zone (Thorup-Kristensen, 1994). Thus, the combination of ryegrass, white and red clover can be used for an efficient ecological intensification of organic spring oat production in Denmark, both for increasing yields and reducing $\mathrm{N}$ leaching irrespectively of soil type or time of ploughing.

\subsection{Ecological intensification of spring barley}

The impact of growing catch crops prior to spring barley on the cereal yield varied between sites, crop rotations and manure treatments, and the yield benefit was in general smaller than that observed for spring oats (Tables 4 and 7). A detailed analysis for individual systems revealed no yield improvement due to previous catch crops when spring barley received manure at Foulum, irrespectively of catch crop composition (data not shown), although grain yield still responded to increases of soil $\mathrm{N}$ availability at this site (Doltra et al., 2011). Only in the unmanured treatment of the $\mathrm{O} 4$ rotation was a benefit from previous catch crops observed. A likely cause of this low effect could be that $\mathrm{N}$ mineralization from catch crops were not aligned with crop demand.

A possible difference between spring barley and spring oat affecting the $\mathrm{N}$ recovery is the timing of the vegetative development, where spring oat reached flag leaf emergence a few days later than spring barley. This slower development in spring oats gives a longer time for taking up the mineralized $\mathrm{N}$, and also a longer time for the crop to benefit in terms of developing a sufficiently high leaf area. It may also be that manure and catch crops affect root growth and $\mathrm{N}$ uptake in roots differently in the two crops thus giving rise to differential effects on above-ground crop growth. Chirinda et al. (2012) observed a considerable amount of $\mathrm{N}$ in roots of spring barley grown after catch crops, even when the above-ground biomass seemed to be lacking N. Spring barley had a strong N demand during early growth as indicated by the higher total above-ground $\mathrm{N}$ at this stage of the cereal observed in the $-\mathrm{CC} /+\mathrm{M}$ in comparison with the $+\mathrm{CC} /+\mathrm{M}$ or the unmanured systems of the $\mathrm{O} 2$ rotation at Foulum (Fig. 6). This indicates a delay in availability of incorporated $\mathrm{N}$ in catch crops, and this would partly explain the low benefits in grain yield obtained from the residues of previous catch crop.

There was in general a better response of spring barley yield to $\mathrm{N}$ in catch crops at Jyndevad than at Foulum and Flakkebjerg, which is in line with observations by Olesen et al. (2007). This may have been caused by the low nutrient retention capacity at this soil type, which makes little $\mathrm{N}$ available in treatments without catch crops. However, at this location the soil may over time develop nutrient deficiencies unless manure is applied. This possible lack of other nutrients than $\mathrm{N}$ is also indicated by the increasing yield gap over time between the unmanured and manured treatments (Figs. 2 and 3). Lack of correlation between autumn $\mathrm{N}$ in catch crops and in the subsequent spring barley crop was previously reported by Thorup-Kristensen (1994) in unfertilized plots, who suggested that this could be alleviated by changing the timing of growing and incorporation of catch crops. Olesen et al. (2007) also analyzed the effects of catch crop $\mathrm{N}$ on spring barley grain yield using data from the two first cycles of the $\mathrm{O} 2$ rotation. They found significant contributions of catch crops to grain $\mathrm{N}$ yield corresponding to $0.52,0.33$ and $0.16 \mathrm{~kg} \mathrm{~kg}^{-1} \mathrm{~N}$, for Jyndevad, Foulum and Flakkebjerg (corresponding to the parameter estimates in Table 7). These values are slightly different from those found on this study $\left(0.46 \mathrm{~kg} \mathrm{~kg}^{-1} \mathrm{~N}\right.$ on average for the three locations), but they also included measurements in the treatments without catch crops. We found no significant effects of crop rotation on the $\mathrm{N}$ recovery efficiency.

Spring barley was grown with an undersown grass-clover mixture (ryegrass, white clover and red clover) as catch crop (O4 rotation) or green manure crop ( $\mathrm{O} 2$ rotation). The interspecific competition between spring barley and the undersown grass-clover was affected by location and crop $\mathrm{N}$ supply (manure and catch crops). In the situations with the highest crop $\mathrm{N}$ supply (i.e. $+\mathrm{CC} /+\mathrm{M}$ at Foulum) growth of the undersown grass-clover was limited by a dense spring barley canopy, which reduced light in the bottom of the canopy and resulted in low grass-clover DM after cereal harvest (Fig. 4) and little clover DM at the first cutting in the following year (Table 8 and Fig. 5). When crop N supply was low and cereal growth was limited, the undersown legume plants had the better conditions for growing, because of less competition for light and soil resources, while still obtaining $\mathrm{N}$ from BNF (Table 8 and Fig. 5). At Jyndevad low availability of soil nutrients in the-M treatment may have limited growth of both the spring barley and the catch crop, and application of manure was positive for the cereal and 
the grass-clover. Despite apparent problems with establishment of grass-clover at Jyndevad, it is at this site that growing catch crops had the best effect on spring barley yields in both $\mathrm{O} 2$ (Fig. 3) and 04 (Fig. 2) rotations. Olesen et al. (2007) estimated yield benefits from catch crops of about $0.4 \mathrm{Mg} \mathrm{ha}^{-1}$ at Jyndevad in the $\mathrm{O} 2$ rotation for the first two cycles, and this would increase to $0.6 \mathrm{Mg} \mathrm{ha}^{-1}$ if the averages of all three cycles are considered (Table 4).

Our results did not allow the effect of interspecific competition on cereal yield to be directly determined. However, the effect of lower $\mathrm{N}$ in undersown catch crops $\left(N_{c}\right)$ observed with larger spring barley yield was estimated, as for spring oat, using the parameter values in Table 7. This resulted in an average $N_{c}$ of $2.5 \mathrm{~kg} \mathrm{~N} \mathrm{Mg}^{-1} \mathrm{DM}$ yield that, considering a $N_{\text {rec }}$ of $0.46 \mathrm{~kg} \mathrm{~kg}^{-1}$ (Table 7), is less than the overall increases of grain Nyield in the systems with catch crops (Table 4). The effect was also site dependent and ranged from 0.6 to $3.9 \mathrm{~kg} \mathrm{~N} \mathrm{Mg}^{-1} \mathrm{DM}$ yield at Flakkebjerg and Foulum, respectively. Other Nordic experiment with undersown perennial ryegrass and clover has shown little effect on cereal grain yield (Känkänen and Eriksson, 2007), while reduction of spring barley yield with undersown Italian ryegrass was found by these authors as well as by Thorup-Kristensen (1994). These results underline the importance of considering soil type and management as well as crop species when growing efficient catch crops by undersowing in spring barley.

Catch crops have the ability to considerably reduce nitrate leaching from spring barley crops (Askegaard et al., 2005, 2011; Doltra et al., 2011). This should conserve $\mathrm{N}$ within the system and lead to long-term fertility effects that would be able to improve grain yields as shown in this and other studies (Berntsen et al., 2006). However, the present results show that short-term effects of catch crops may be smaller in spring barley than in spring oats. It may be possible to improve the short-term effects of catch crops in spring barley, either by choosing catch crop species with a faster release of $\mathrm{N}$ in spring or by harvesting the catch crop biomass and convert this into a fertilizer (e.g., through biogas digestion) (Stinner et al., 2008).

\subsection{Short and long-term implications of catch crops}

In this study we have shown that the effect of catch crops on cereal productivity within organic arable rotations depends on the cereal and catch crop species, crop management and soil type. This would be also the case for the effects of catch crops on the environment through $\mathrm{N}$ leaching, $\mathrm{N}_{2} \mathrm{O}$ emissions and soil carbon sequestration (Askegaard et al., 2005; Olesen et al., 2009; Chirinda et al., 2010; Doltra et al., 2011). All these factors, therefore, are to be considered when deciding on catch crop mixture composition, seeding rate, sowing date and time of incorporation. Improving cereal yields in organic farming will depend on increasing short and long-term soil fertility, which may be obtained by increasing the proportion of legume species in the catch crop mixture, as legumes provide $\mathrm{N}$ input through BNF (Thorup-Kristensen, 1994; Känkänen and Eriksson, 2007; Campiglia et al., 2009). This would not jeopardize the reduction of $\mathrm{N}$ leached below rooting depth (Thorup-Kristensen, 1994; Askegaard and Eriksen, 2008; Askegaard et al., 2011). However, in situations with high $\mathrm{N}$ leaching, it would be preferable to grow species that develop a deep rooting system, such as fodder radish (Thorup-Kristensen, 1994), to recycle the $\mathrm{N}$ otherwise leached in the rotation system.

Our results show that $\mathrm{N}$ supply to cereals in organic crop rotations is affected by several interacting factors, including the crop rotation, application of manure and growing of catch crops, and the effect of these factors also depend on soil type. To improve the estimation of catch crops contribution to crop $\mathrm{N}$ supply requires a better understanding of the temporal release of $\mathrm{N}$ in catch crops compared with crop $\mathrm{N}$ demand, and gain a better knowledge on its role for long-term soil fertility. In this respect, well-validated modeling approaches are highly valuable tools in the agronomic research for ecological intensification. For instance, long-term simulations of using ryegrass catch crops in Nordic conditions showed increases of spring barley yield by using $\mathrm{N}$ that was not leached, but also increased $\mathrm{N}$ losses due to leaching or denitrification as soil $\mathrm{N}$ turnover increases (Berntsen et al., 2006). Simulation models for organic farming should also consider the competition between the main crop and undersown catch crops, and in this respect it would be desirable to include a weed component in the models, since weeds interact with catch crops and also contribute to reducing cereal yields (Olesen et al., 2004, 2009).

\section{Conclusions}

Grain yields of spring cereals were significantly improved by growing catch crops in organic crop rotations irrespectively of manure application. However, the magnitude of the effect depended on cereal and catch crop species, soil and rotation type, and the application of $\mathrm{N}$ in manure. Spring oats were more responsive to catch crops than spring barley, and showed higher apparent $\mathrm{N}$-recovery efficiency than spring barley. The improved spring barley yields observed in the treatments with catch crops may be partly caused by a long-term fertility building effect in these systems. Competition between the cash crops and the undersowing catch crops reduced $\mathrm{N}$ uptake of catch crop and thus also $\mathrm{N}$ supply to the following cereal crop. Our results indicate that there is a high potential to improve yields in organic cereal systems through improved management of catch crops (e.g., proportion of legumes and selection of the better adapted species/varieties and operation timing). This requires a more detailed knowledge of the short and long term $\mathrm{N}$ cycling of catch crop residues for specific crop rotations and soils.

\section{Acknowledgements}

The work was supported by the CROPSYS project under the International Centre for Research in Organic Food Systems (ICROFS), by the EU-FP7 Legume Futures project, and by the Danish Ministry of Food, Agriculture and Fisheries.

\section{References}

Askegaard, M., Eriksen, J., 2008. Residual effect and leaching of $\mathrm{N}$ and $\mathrm{K}$ in cropping systems with clover and ryegrass catch crops on coarse sand. Agric. Ecosyst. Environ. 123, 99-108.

Askegaard, M., Olesen, J.E., Rasmussen, I.A., Kristensen, K., 2005. Nitrate leaching from organic arable crop rotations: effects of location, manure and catch crop. Soil Use Manage. 21, 181-188.

Askegaard, M., Olesen, J.E., Kristensen, K., 2011. Nitrate leaching from organic arable crop rotations is mostly determined by autumn field management. Agric. Ecosyst. Environ. 142, 149-160.

Berntsen, J., Hauggard-Nielsen, H., Olesen, J.E., Petersen, B.M., Jensen, E.S., Thomsen, A., 2004. Modelling dry matter production and resource use in intercrops of pea and barley. Field Crops Res. 88, 69-83.

Berntsen, J., Olesen, J.E., Petersen, B.M., Jensen, E.S., 2006. Long-term fate of nitrogen uptake in catch crops. Eur. J. Agron. 25, 383-390.

Brisson, N., Gate, P., Gouache, D., Charmet, G., Oury, F.X., Huard, F., 2010. Why are wheat yields stagnating in Europe? A comprehensive data analysis for France. Field Crops Res. 119, 201-212.

Buchmann, N.B., Josefsson, H., Cowe, I.A., 2001. Performance of European artificial neural network (ANN) calibration for moisture and protein in cereals using the Danish near-infrared transmission (NIT) network. Cereal Chem. 78, 572-577.

Campiglia, E., Paolini, R., Colla, G., Mancinelli, R., 2009. The effects of cover cropping on yield and weed control of potato in a transitional system. Field Crops Res. $112,16-23$

Cassman, K.G., 1999. Ecological intensification of cereal production systems: yield potential, soil quality, and precision agriculture. Proc. Natl. Acad. Sci. U.S.A. 96, 5952-5959.

Chirinda, N., Carter, M.S., Albert, K.R., Ambus, P., Olesen, J.E., Porter, J.R., Petersen, S.O., 2010. Emissions of nitrous oxide from arable organic and conventional cropping systems on two soil types. Agric. Ecosyst. Environ. 136, 199-208. 
Chirinda, N., Olesen, J.E., Porter, J.R., 2012. Root carbon input in organic and inorganic fertilizer-based systems: exploring a black box. Plant Soil., doi:10.1007/s11104012-1208-5.

Dobermann, A., Cassman, K.G., 2005. Cereal area and nitrogen use efficiency are drivers of future nitrogen fertilizer consumption. Sci. China Ser. C: Life Sci. 48 , 745-758.

Doltra, J., Lægdsmand, M., Olesen, J.E., 2011. Cereal yield and quality as affected by nitrogen availability in organic and conventional arable crop rotations: a combined modeling and experimental approach. Eur. J. Agron. 34, 83-95.

Doré, T., Makowski, D., Malézieux, E., Munier-Jolain, N., Tchamitchian, M., Tittonell, P., 2011. Facing up to the paradigm of ecological intensification in agronomy. Revisiting methods, concepts and knowledge. Eur. J. Agron. 34, 197-210.

Engström, L., Stenberg, M., Aronsson, H., Lindén, B., 2010. Reducing nitrate leaching after winter oilseed rape and peas in mild and cold winters. Agron. Sustain. Dev., doi:10.1051/agro/2010035.

Finger, R., 2010. Evidence of slowing yield growth-the example of Swiss cereal yields. Food Policy 35, 175-182.

Finger, R., 2011. Food security: close crop yield gap. Nature 480, doi:10.1038/480039e.

Foresight, 2011. The Future of Food and Farming: Challenges and Choices for Global Sustainability. The Government Office for Science, London, UK.

Hansen, B., 1989. Determination of nitrogen as elementary N, an alternative to Kjeldahl. Acta Agric. Scand. 39, 113-118.

Hauggaard-Nielsen, H., Mundus, S., Jensen, E.S., 2009a. Nitrogen dynamics following grain legumes and subsequent catch crops and the effects on succeeding cereal crops. Nutr. Cycl. Agroecosyst. 84, 281-291.

Hauggaard-Nielsen, H., Gooding, M., Ambus, P., Corre-Hellou, G., Crozat, Y., Dahlmann, C., Dibet, A., von Fragstein, P., Pristeri, A., Monti, M., Jensen, E.S. 2009b. Pea-barley intercropping and short-term subsequent crop effects across European organic cropping conditions. Nutr. Cycl. Agroecosyst. 85, 141-155.

Hochman, Z., Carberry, P.S., Robertson, M.J., Gaydon, D.S., Bell, L.W., McIntosh, P.C., 2011. Prospects for ecological intensification of Australian agriculture. Eur. J. Agron. 44, 109-123.

Känkänen, H., Eriksson, C., 2007. Effects of undersown crops on soil mineral $\mathrm{N}$ and grain yield of spring barley. Eur. J. Agron. 27, 25-34.

Lampkin, N., 1998. Organic Farming. Farming Press, Ipswich, 715 pp.

Magid, J., Henrikisen, O., Thorup-Kristensen, K., Mueller, T., 2001. Disproportionately high $\mathrm{N}$-mineralisation rates from green manure at low temperatures-implications for modeling and management in cool temperate agro-ecosystems. Plant Soil 228, 73-82.

MEA, 2005. Environmental degradation and human well-being: report of the millennium ecosystem assessment. Pop. Dev. Rev. 31, 389-398.

Olesen, J.E., Askegaard, M., Rasmussen, I.A., 2000. Design of an organic farming crop rotation experiment. Acta Agric. Scand. Soil Plant Sci. B 50, 13-21.
Olesen, J.E., Hansen, P.K., Berntsen, J., Christensen, S., 2004. Simulation of aboveground suppression of competing species and competition tolerance in winter wheat varieties. Field Crops Res. 89, 263-280.

Olesen, J.E., Hansen, E.M., Askegaard, M., Rasmussen, I.A., 2007. The value of catch crops and organic manures for spring barley in organic arable farming. Field Crops Res. 100, 168-178.

Olesen, J.E., Askegaard, M., Rasmussen, I.A., 2009. Winter cereal yields as affected by animal manure and green manure in organic arable farming. Eur. J. Agron. 30, 119-128.

Plantedirektoratet, 1997. Vejledning og skemaer, mark- og gødningsplan, gødnings regnskab, grønne marker 1997/98 (Guidelines and Schemes, Field- and Fertilization-plans, Fertilization Accounts, Green Fields 1997/98). Plantedirektoratet, Lyngby, Denmark.

Plantedirektoratet, 2005. Vejledning om økologisk jordbrugsproduktion, Februar 2005 (Guidelines for 35 Organic Farming Production, February 2005). Danish Plant Directorate, 36 Skovbrynet 20, DK-2800 Lyngby.

Rasmussen, I.A., Askegaard, M., Olesen, J.E., Kristensen, K., 2006. Effects of weeds management in newly converted organic crop rotations in Denmark. Agric. Ecosyst. Environ. 113, 184-195.

SAS Institute Inc., 2008. SAS ${ }^{\circledR}$ 9.2. Procedures Guide: Statistical Procedures. SAS Institute Inc., 20 Cary, NC, USA, 492 pp.

Schjønning, P., de Jonge, L.W., Munkholm, L.J., Moldrup, P., Christensen, B.T., Olesen J.E., 2012. Drivers for dispersibility and soil friability-test of the clay carbon saturation concept. Vadose Zone J., doi:10.2136/vzj2011.0067.

Stinner, W., Möller, K., Leithold, G., 2008. Effects of biogas digestion of clover/grass leys, cover crops and crop residues on nitrogen cycle and crop yield in organic stockless farming systems. Eur. J. Agron. 29, 125-134.

Thorsted, M.D., Olesen, J.E., Koefoed, N., 2002. Effects of white clover cultivars on biomass and yield in oat/clover intercrops. J. Agric. Sci. 138, 261-267.

Thorup-Kristensen, K., 1994. The effect of nitrogen catch crops species on the nitrogen nutrition of succeeding crops. Fertil. Res. 37, 227-234

Thorup-Kristensen, K., Magid, J., Jensen, L.S., 2003. Catch crops and green manures as biological tools in nitrogen management in temperate zones. Adv. Agron. 79, 227-302.

Thorup-Kristensen, K., Dresbøll, D.B., 2010. Incorporation time of nitrogen catch crops influences the $\mathrm{N}$ effect for the succeeding crop. Soil Use Manage. 26 27-35.

Tonitto, C., David, M.B., Drinkwater, L.E., 2006. Replacing bare fallows with cover crops in fertilizer-intensive systems. A meta-analysis of crop yield and $\mathrm{N}$ dynamics. Agric. Ecosyst. Environ. 112, 58-72.

United Nations, 2005. World Population Prospects: The 2004 Revision, Volume III: Analytical Report. United Nations, New York. 